\title{
Histological analysis of biocompatibility of ionomer cements with an acid-base reaction
}

Rogério Lacerda DOS SANTOS(a) Mirella de Fátima Liberato DE MOURA ${ }^{(a)}$

Fabiola Galbiatti DE CARVALHO(a) Gymenna Maria Tenório GUÊNES(b)

Polliana Muniz ALVES(c)

Matheus Melo PITHON(d)

(a) Clínica Infantil, Curso de Odontologia, Universidade Federal de Campina Grande UFCG, Patos, PB, Brazil.

(b) Odontologia Restauradora, Curso de Odontologia, Universidade Federal de Campina Grande - UFCG, Patos, PB, Brazil.

(c) Patologia Bucal, Curso de Odontologia, Universidade Estadual da Paraíba - UEPB, Campina Grande, PB, Brazil.

(d) Ortodontia, Curso de Odontologia, Universidade Estadual do Sudoeste da Bahia - UESB, Jequié, BA, Brazil.

Declaration of Interests: The authors certify that they have no commercial or associative interest that represents a conflict of interest in connection with the manuscript.

Corresponding Author:

Rogério Lacerda dos Santos

Email: lacerdaorto@hotmail.com

http://dx.doi.org/10.1590/S1806-83242014.50000003 Epub Jan 24, 2014

Submitted: Jan 25, 2013

Accepted for publication: Oct 25, 2013

Last revision: Nov 25, 2013

\begin{abstract}
The purpose of this study was to evaluate the inflammatory and cure events of acid-based reactions using glass ionomer cement used for cementation of crowns, bridges, onlays and orthodontic bands implanted in subcutaneous tissue, at different time intervals. A total of 48 male Wistar rats were used, distributed into 4 groups $(\mathrm{n}=12)$, as follows: Group C (control, polyethylene), Group ME (Meron), Group KC (Ketac Cem) and Group PR (Precedent). The animals were sacrificed after time intervals of 7, 15 and 30 days, and their tissues were analyzed under an optical microscope for such events as inflammatory infiltrate, edema, necrosis, granulation tissue, multinucleated giant cells, young fibroblasts and collagen. The results was assessed using Kruskal-Wallis and Dunn's tests $(p<0.05)$. In the initial period, intense inflammatory infiltrate was observed for all the materials with no significant difference among them $(p=0.104)$. Groups PR and KC showed significant difference in relation to Group $C$, at 7 days $(p=0.025)$ and 15 days $(p=0.006)$. Edema and giant cells were more expressive in Group ME, differing significantly from Groups C ( $p=0.023)$ and KC $(p=0.039)$, respectively, at 7 days. Group ME showed a statistically significant difference in relation to Groups PR and $\mathrm{KC}$ for the presence of young fibroblasts $(p=0.009)$ and for collagen $(p=0.002)$, at 7 days. Within the limits of this in vivo study, Precedent and Ketac Cem glass ionomer cements showed better tissue healing with a greater number of fibroblasts and collagen, as compared to Meron.
\end{abstract}

Keywords: Biocompatible Materials; Glass Ionomer Cements; Dentistry.

\section{Introduction}

There has been a growing concern about the biocompatibility of dental materials over the last few years, including glass ionomer cements (GICs). ${ }^{1,2,3}$ GIC powder is a calcium fluoroaluminosilicate glass, frequently associated with other components, such as lanthanum, strontium, barium oxide and zinc oxide. The acid used in most GICs is an aqueous solution of polyacrylic and tartaric acid. ${ }^{1,4}$ Organic acids from the polyacrylic acid chains react with the glass powder, breaking the Al-O-Si bonds, and releasing aluminum and calcium ions in an aqueous medium., ${ }^{1,4}$

Some studies ${ }^{5-7}$ have demonstrated that the cytotoxic effects of GICs may be attributed to the metal components released, such as aluminum and iron. ${ }^{8-9}$ Data obtained in studies of odontoblastic cell lineages report the solubility of these experimental materials and their possible toxic 
Table 1. Composition of the tested glass ionomer cements (GICs).

\begin{tabular}{|l|c|c|c|c|}
\hline Group & GIC & Composition & Manufacturer \\
\hline ME & Meron & $\begin{array}{c}\text { Powder: fluoroaluminosilicate glass, polyacrylic acid and } \\
\text { pigments } \\
\text { Liquid: water, tartaric acid, initiators }\end{array}$ & VOCO \\
\hline KC & Ketac-Cem & $\begin{array}{c}\text { Powder: fluoroaluminosilicate glass, carbonic acid copolymers } \\
\text { (polyacrylic and maleic) and pigments } \\
\text { Liquid: water, tartaric acid and benzoic acid }\end{array}$ & 3 ESPE & 456255 \\
\hline PR & Precedent & $\begin{array}{c}\text { Powder: fluoroaluminosilicate glass, carbonic acid copolymers } \\
\text { and pigments } \\
\text { Liquid: tartaric acid solution }\end{array}$ & RELIANCE & 114960 \\
\hline
\end{tabular}

effects, especially when applied in a humid environment, ${ }^{9}$ as well as their potential to cause damage to gingival tissues. ${ }^{10-11}$

Research on the biocompatibility of materials has been conducted ${ }^{12-14}$ to date; however, there are only few studies that relate the inflammatory and cure events of GICs in vivo. The proximity of the gingival tissues to prostheses and orthodontic bands cemented with GICs makes the biocompatibility of these cements an important factor that must be borne in mind when opting for their use in clinical practice. The aim of this study was to evaluate the inflammatory and cure events of GICs with an acid-base reaction, used for cementation and implanted in subcutaneous tissue, at different time intervals.

\section{Methodology}

\section{Animal model and experimental groups}

A total of 48 adult male Wistar rats with a mean weight of $250 \mathrm{~g}$, belonging to the vivarium of the Unidade Acadêmica de Ciências Biológicas/Universidade Federal de Campina Grande - UACB/UFCG, were used in this study. The animals were divided into 4 experimental groups:

- Group C (control, polyethylene tube),

- Group ME (Meron, VOCO, Cuxhaven, Germany),

- Group KC (Ketac Cem, 3M ESPE, Seefeld, Germany) and

- Group PR (Precedent, Reliance Orthodontic Products, Inc., Itasca, USA; Table 1).

The rats were anesthetized with an intraperitoneal injection of sodium thiopental $(50 \mathrm{mg} / \mathrm{kg}$; Cristália, Campinas, Brazil). Hair removal was then performed on the dorsal region of each animal $(4 \times 4 \mathrm{~cm})$. Animal experimentation was approved by the Ethics Committee on Animal Research, Centro de Saúde e Tecnologia Rural - CSTR/UFCG, Protocol CEP no. 0102011.

A 4\% chlorhexidine gluconate solution was used for antisepsis of the operative field..$^{15}$ Two incisions approximately $8 \mathrm{~mm}$ long were made in the midline, equidistant from the tail base to the head of the animal, using a no. 15 scalpel blade (Embramac, Itapira, Brazil) adapted to a scalpel handle.

Using a blunt tipped scissors (Duflex, SS White Ltda., Rio de Janeiro, Brazil), the subcutaneous tissue was parted laterally to promote a tunnel in the lateral direction, forming two surgical recesses, each approximately $18 \mathrm{~mm}$ deep. Each rat received two tube implants $(1.5 \mathrm{~mm}$ inner diameter $\times 5 \mathrm{~mm}$ long) made of polyethylene (nontoxic Scalp Vein 19G, Embramac, Itapira, Brazil). Before use, the implants were kept in $70 \%$ alcohol for 120 minutes, washed with deionized water and autoclaved at a temperature of $110^{\circ} \mathrm{C}$ for 20 minutes, after which they were used as inoculation vehicles for the tested materials.

The experimental materials were handled according to the manufacturers' instructions, that is, respecting the recommended ratio of powder/liquid and using paper blocks and a plastic spatula, previously autoclaved at a temperature of $110^{\circ} \mathrm{C}$ for 20 minutes. The GICs were introduced into the openings at the extremities of the tubes, using a syringe (Centrix, Shelton, USA) supported on a glass slide at one extremity and on a small glass slide at the other, to flatten the material.

After the GICs hardened, the tubes were implanted and the surgical recesses were sutured with a 4.0 suture needle and thread (Ethicon, Johnson \& Johnson, São José dos Campos, Brazil). The animals then received a $0.2 \mathrm{~mL}$ intramuscular dose of veterinary pentabiotic 
(Wyeth Ayerst Laboratory, New York, USA), and an injection of sodium dipyrone $(0.3 \mathrm{~mL} / 100 \mathrm{~g}$, Novalgina, São Paulo, Brazil). All the procedures of this study were performed in accordance with the guidelines of the Canadian Council on Animals Care (1981). The animals were kept in individual cages under adequate conditions, with appropriate rations and water ad libitum.

After time intervals of 7, 15 and 30 days, the animals were anesthetized to obtain excisional biopsies of the implant area, including sufficient normal surrounding tissue. Afterwards, the rats were sacrificed using the cervical dislocation technique, after having been sedated with sodium thiopental $(50 \mathrm{mg} / \mathrm{kg}$; Cristália Ltda., Campinas, Brazil).

\section{Biocompatibility}

After the rats were sacrificed, samples were taken and submitted to fixation in $4 \%$ formaldehyde (Mil- ony solution) for $24 \mathrm{~h}$, and then embedded in paraffin to obtain serial and histological $6-\mu \mathrm{m}$ thick sections, and stained with hematoxylin and eosin. The inflammatory tissue reaction induced by the composites was evaluated by a blind examiner using a light microscope (BX40; Olympus, Hamburg, Germany) at $100 \times, 200 \times$ and $400 \times$ magnification. The examiner was calibrated before data analysis (kappa $=0.7$ ). Five representative histological sections were evaluated for each sample of the study.

The presence of inflammatory infiltrate, edema, necrosis, granulation tissue, multinuclear giant cells, young fibroblasts and collagen was assigned points according to the following scores:
1. absent,
2. scarce,
3. moderate and
4. intense.

Table 2. Mean scores attributed to cements and control group, after time intervals of 7, 15 and 30 days, for the 7 events evaluated.

\begin{tabular}{|c|c|c|c|c|c|c|}
\hline \multirow[t]{2}{*}{ Event } & \multirow[t]{2}{*}{ Time } & \multicolumn{4}{|c|}{ Group } & \multirow[t]{2}{*}{$p$} \\
\hline & & ME & $\mathrm{KC}$ & PR & C & \\
\hline \multirow[t]{3}{*}{ Inflammatory infiltrate } & 7 days & $16.25^{\mathrm{AB}}$ & $18.75^{A}$ & $18.75^{\mathrm{A}}$ & $11.25^{\mathrm{B}}$ & 0.025 \\
\hline & 15 days & $11.25^{\mathrm{AB}}$ & $15.00^{\mathrm{A}}$ & $15.00^{A}$ & $10.00^{\mathrm{B}}$ & 0.006 \\
\hline & 30 days & 10.00 & 10.00 & 11.25 & 7.50 & 0.104 \\
\hline \multirow[t]{3}{*}{ Edema } & 7 days & $13.75^{\mathrm{A}}$ & $7.50^{\mathrm{AB}}$ & $11.25^{\mathrm{AB}}$ & $6.25^{B}$ & 0.023 \\
\hline & 15 days & 5.00 & 5.00 & 5.00 & 5.00 & 1.000 \\
\hline & 30 days & 6.25 & 5.00 & 5.00 & 5.00 & 0.391 \\
\hline \multirow[t]{3}{*}{ Necrosis } & 7 days & 6.25 & 5.00 & 5.00 & 5.00 & 0.391 \\
\hline & 15 days & 5.00 & 5.00 & 5.00 & 5.00 & 1.000 \\
\hline & 30 days & 5.00 & 5.00 & 5.00 & 5.00 & 1.000 \\
\hline \multirow[t]{3}{*}{ Granulation tissue } & 7 days & 18.75 & 18.75 & 18.75 & 18.75 & 1.000 \\
\hline & 15 days & 11.25 & 10.00 & 10.00 & 7.50 & 0.104 \\
\hline & 30 days & 13.75 & 7.50 & 13.75 & 12.50 & 0.055 \\
\hline \multirow[t]{3}{*}{ Giant cells } & 7 days & $10.00^{\mathrm{B}}$ & $5.00^{A}$ & $7.50 \mathrm{~A}^{\mathrm{AB}}$ & $6.25^{\mathrm{AB}}$ & 0.039 \\
\hline & 15 days & $5.00^{\mathrm{B}}$ & $5.00^{\mathrm{B}}$ & $12.50^{\mathrm{A}}$ & $6.25^{A B}$ & 0.006 \\
\hline & 30 days & $6.25^{A B}$ & $5.00^{B}$ & $10.00^{\mathrm{A}}$ & $5.00^{B}$ & 0.008 \\
\hline \multirow[t]{3}{*}{ Young fibroblasts } & 7 days & $5.00^{A}$ & $12.50^{B}$ & $11.25^{\mathrm{B}}$ & $10.00^{\mathrm{AB}}$ & 0.009 \\
\hline & 15 days & 16.25 & 17.50 & 18.75 & 15.00 & 0.171 \\
\hline & 30 days & 15.00 & 18.75 & 17.50 & 15.00 & 0.061 \\
\hline \multirow[t]{3}{*}{ Collagen } & 7 days & $5.00^{A}$ & $10.00^{B}$ & $10.00^{B}$ & $10.00^{B}$ & 0.002 \\
\hline & 15 days & 12.50 & 13.75 & 12.50 & 15.00 & 0.391 \\
\hline & 30 days & 15.00 & 17.50 & 18.75 & 15.00 & 0.061 \\
\hline
\end{tabular}

$p=$ Non-parametric Kruskal-Wallis test, followed by Dunn's multiple comparisons test; Means followed by different letters express a statistically significant difference $(p<0.05)$. 

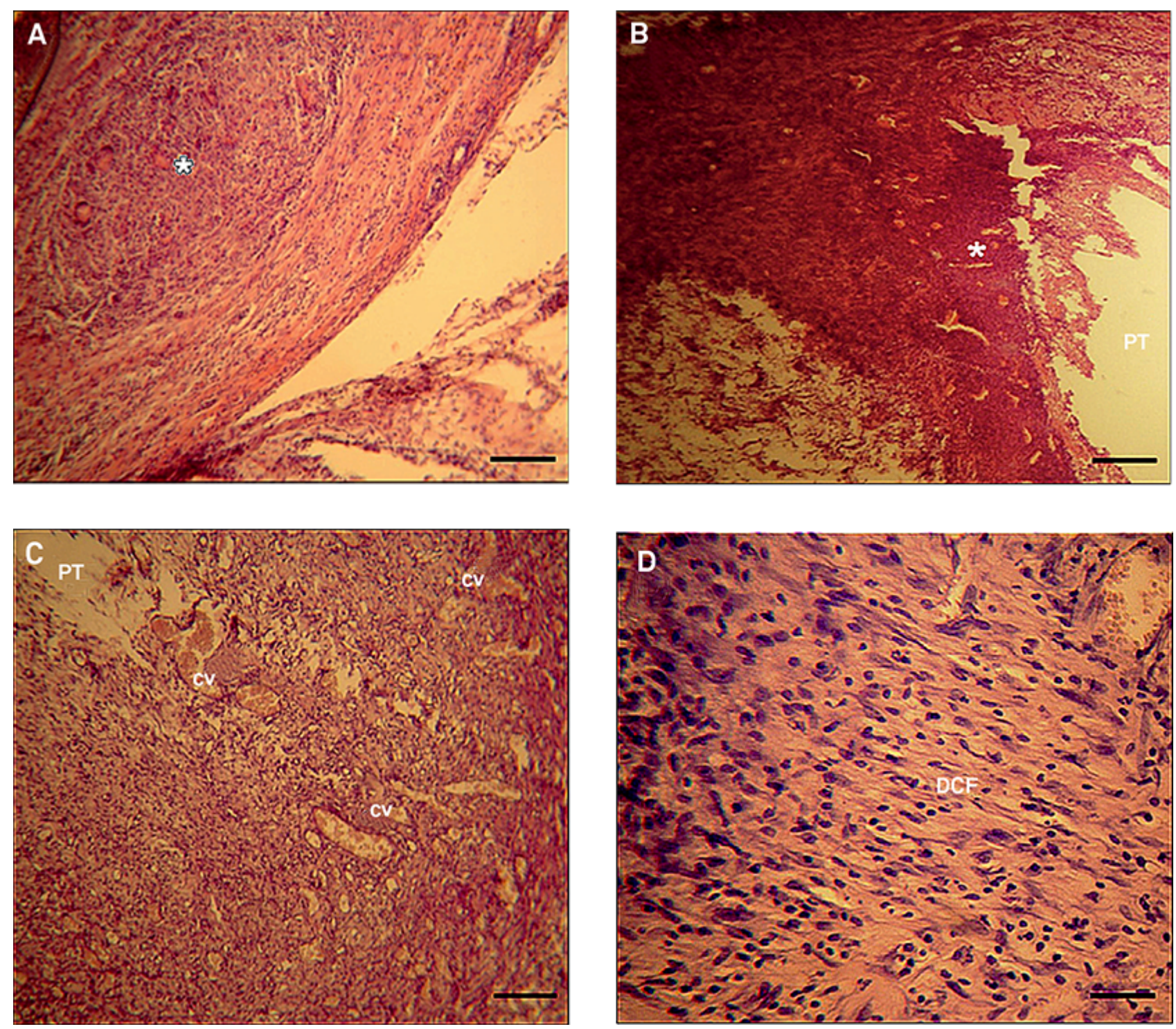

Figure 1. Photomicrograph of a histological sample. A: 15 days after implantation, Group PR: moderate inflammatory infiltrate, with focal distribution $(*)$, composed of numerous multinucleated giant cells $(\mathrm{HE}, 100 \times$ magnification; scale: $100 \mu \mathrm{m})$. B: 7 days after implantation, Group KC: focal area $\left(^{*}\right)$ of mononuclear inflammatory cells (HE, 100× magnification; scale: $\left.100 \mu \mathrm{m}\right)$. C: 7 days after implantation, Group $\mathrm{C}$ (control): granulation reaction area with congested vessels (CV; HE, 100× magnification; scale: $100 \mu \mathrm{m})$. D: 30 days after implantation, Group ME: proliferation of young fibroblasts with a fusiform aspect, in the midst of deposition of collagen fibers (DCF), the majority of which were shown to be disposed in parallel bundles. Diminutive blood vessels could also be seen (HE, $400 \times$ magnification; scale: $25 \mu \mathrm{m})$. Area of the polyethylene tube implant (PT).

\section{Statistical analysis}

The data were tabulated and analyzed in the BioEstat statistical program version 5.0 (Instituto Mamirauá, Manaus, Brazil). The results of the cellular events were submitted to the Kruskal-Wallis nonparametric test, followed by Dunn's test to determine the differences among the groups $(p<0.05)$, insofar as the results did not present normal distribution.

\section{Results}

In the initial period, intense inflammatory infiltrate was observed for all the materials, with no significant statistical difference among them $(p=0.104)$. Groups PR (Figure 1A) and KC (Figure 1B) showed significant statistical difference in relation to Group $C$ (Figure $1 C)$, at 7 days $(p=0.025)$ and 15 days $(p=0.006$; Table 2). 
Circulatory alterations (edema) were more significant in Group ME, differing significantly from Group C ( $p=0.023)$ at 7 days. In the events regarding tissue degeneration (necrosis) and granulation tissue around and within the cavity, the materials demonstrated similar behavior, with little or no necrosis and expressive response of tissues at the onset of the repair process, with no statistical difference among the groups $(p>0.05)$. Multinucleated giant cells were more evident in Group ME on the $7^{\text {th }}$ day, with a statistical difference $(p=0.039)$ between Groups ME and KC, which did not persist at 15 and 30 days (Figure 1D). Group PR (Figure $1 \mathrm{~A})$ presented a statistical difference in relation to Groups KC and ME at 15 days ( $p=0.006$ ), a significant difference that persisted between Group $\mathrm{PR}$ and $\mathrm{KC}$ at day 30 ( $p=0.008$; Table 2$)$ in regard to the giant cells.

In relation to the tissue repair events, Group ME was less expressive and showed a statistically significant difference, in relation to Groups PR and KC, for the presence of young fibroblasts $(p=0.009)$ and for collagen $(p=0.002)$ at 7 days (Table 2$)$.

\section{Discussion}

GICs are used for cementation, especially for the fixation of crowns, bridges, onlays and orthodontic bands, because of their clinical properties, which include fluoride release and bonding to tooth structure. ${ }^{16}$ Nevertheless, for a cement to be adequate for clinical use, its components must be biocompatible. ${ }^{15,17-21}$

In this context, the aim of the present experiment was to show evidence of the action of different dental ionomers on tissues, by means of histological analysis. This analysis must fundamentally be based on how live vascularized tissue is influenced by aggression, which may be associated with cell death and necrosis, and how this aggression influences the developmental characteristics of capsule collagenization, inflammatory infiltrate and macrophage action. Moreover, the analysis should be performed by means of qualitative and quantified evaluation. .112,15 $^{-1}$

Biocompatibility studies ${ }^{22-23}$ have used polyethylene tubes as controls, ${ }^{22}$ because they are considered harmless to the epithelial and conjunctive tissue. For this reason, they were used as such in this experiment. ${ }^{15}$
In this study, inflammatory infiltrate and edema events were expressive and intense. No significant difference among the cements was observed on the $7^{\text {th }}$ day in regard to these events, and the events became gradually less intense and similar in subsequent periods, as a response to the presence of metal ions, ${ }^{8-9,20}$ such as those of the aluminum present in all the cements used in this study. These ions are released in the tissue as a result of the presence and/or concentration of the different acids composing the GICs, such as polyalkenoic acids ${ }^{19,9}$ and benzoic acid. ${ }^{7}$ These acids have been pointed out as being substances capable of causing oxidative stress within the cells and interfering in cellular response. ${ }^{19}$ Moreover, the low $\mathrm{pH}$ of these materials, especially when recently prepared, may have an influence on the potential inflammatory response, ${ }^{8-24}$ as supported by Ribeiro et al. ${ }^{7}$ These authors demonstrated that Ketac Cem cement powder did not induce alteration in cell DNA, whereas measurable genotoxicity was found for Ketac Cem liquid, composed of tartaric and benzoic acid, in all the dilutions tested in cell cultures.

Similarly, Precedent and Ketac Cem cements were shown to stimulate significant inflammatory infiltrate in the first 15 days, in comparison with the control, but showed no significant difference in relation to Meron cement. However, the process of collagenization showed ascending values at 30 days, a performance similar to that observed for other materials. ${ }^{15,22}$

In addition to the inflammatory infiltrate, circulatory alterations (edema) and multinucleated giant cells proved expressively greater with the Meron cement at 7 days, contrary to the respective results observed for the other cements. This was a proportional response of the body to the presence of aluminum and/or iron ions, ${ }^{8-25}$ whereby giant cells are released in the tissue to promote phagocytosis, a process by which the ions are surrounded and contained. Moreover, leachable substances from the GICs may also affect the epithelial cell rate of progression through the cellular cycle. ${ }^{26}$ There was virtually no necrotic event in any of the evaluated tissues receiving the materials. This shows the low level of aggression by cement substances. This aggression could lead to irreversible cell damage and subsequent cell death $^{15,18}$ There was intense tissue granulation at 7 
days, tapering off at 15 and 30 days, demonstrating a time-related healing process.

In comparison with Meron, Precedent and Ketac Cem cements showed more evident cellular curerelated events, signaled by the presence of young fibroblasts, and subsequent collagen fibers, as well as a reduced number of blood vessels. These histological findings corroborate those of Ozturk et al.,10 who demonstrated that Meron cement presented genotoxicity, but relatively less in comparison with the resin cements ${ }^{27}$ or polycarboxylates. ${ }^{10}$

In general, a reaction of chronic development was observed throughout the experiment for all the materials. Polymorphonuclear inflammation was observed in the initial stages. However, progressive collagenization became more expressive throughout the successive periods, in addition to the presence of mononuclear infiltrate and multinucleated giant cells.

Although a reduced number of polymorphonuclear cells were observed in some cases, these cells

\section{References}

1. Wilson AD, Kent BE. The glass-ionomer cement, a new translucent dental filling material. J Appl Chem Biotechnol. 1971 Nov;21(11):313.

2. Mount GJ. Glass ionomers: a review of their current status. Oper Dent. 1999 Mar-Apr;24(2):115-24.

3. Kent BE, Lewis BG, Wilson AD. Glass ionomer cement formulations: I. The preparation of novel fluoroaluminosilicate glasses high in fluorine. J Dent Res. 1979 Jun;58(6):1607-19.

4. Mickenautsch S, Yengopal V, Banerjee A. Pulp response to resin-modified glass ionomer and calcium hydroxide cements in deep cavities: a quantitative systematic review. Dent Mater. 2010 Aug;26(8):761-70.

5. Santos RL, Pithon MM, Martins FO, Romanos MT, Ruellas AC. Evaluation of cytotoxicity and degree of conversion of glass ionomer cements reinforced with resin. Eur J Orthod. 2012 Jun;34(3):362-6.

6. Costa CA, Giro EM, Nascimento AB, Teixeira HM, Hebling J. Short-term evaluation of the pulpo-dentin complex response to a resin-modified glass-ionomer cement and a bonding agent applied in deep cavities. Dent Mater. 2003 Dec;19(8):73946.

7. Ribeiro DA, Marques ME, Salvadori DM. Genotoxicity and cytotoxicity of glass ionomer cements on Chinese hamster ovary (CHO) cells. J Mater Sci Mater Med. 2006 Jun;17(6):495500 . were conditioned by an active reactionary process, as seen in the time interval of 15 days for Precedent and Ketac Cem cements. Generally speaking, the expressive response in the initial events, such as the response to irritation, tended to diminish in subsequent and final periods. ${ }^{9,28-29}$

It can be inferred that the clinical use of materials with better biologic behavior must be encouraged, insofar as orthodontic ionomers in flowable form, used for cementation, frequently come into contact with gingival and subgingival tissues, and metal ions and intrinsic acids of the GIC composition may be released both during the setting process and in the degradation of these cements over time. ${ }^{13-14}$

\section{Conclusion}

The GICs showed similar tissue events of inflammation and edema, but Precedent and Ketac Cem cements showed a better tissue-healing process with a greater number of fibroblasts and collagen, as compared to Meron.

8. Oliva A, Salerno A, Locardi B, Riccio V, Della Ragione F, Iardino $\mathrm{P}$, et al. Behaviour of human osteoblasts cultured on bioactive glass coatings. Biomaterials. 1998 Jun;19(1112):1019-25.

9. Coimbra LR, Giro EMA, Aranha AMF, Costa CAS. Cytotoxicity of restorative glass-ionomer cements to an odontoblast cell line. Rev Odonto Cienc. 2006 Jan;54(21):338-45.

10. Ozturk F, Yuksel S, Toy E, Kurtoglu EL, Kuçuk EB. Genotoxic effects of banding procedure with different orthodontic cements on human oral mucosa cells. Turk J Med Sci. 2012 Jul;42(Suppl 1):1157-165.

11. Souza PP, Aranha AM, Hebling J, Giro EM, Costa CA. In vitro cytotoxicity and in vivo biocompatibility of contemporary resin-modified glass-ionomer cements. Dent Mater. 2006 Sep;22(9):838-44.

12. Boaventura JMC, Roberto AR, Becci ACO, Ribeiro BCI, Oliveira MRB, Andrade MF. The Importance of biocompatibility of new materials: review of the glass ionomer cement. Rev Odontol Univ Cid Sao Paulo. 2012 Jan-Abr;24(1):42-50.

13. Kawai K, Takaoka T. Fluoride, hydrogen ion and HEMA release from light-cured GIC restoratives. Am J Dent. 2002 Jun;15(3):14952.

14. Lonnroth EC, Dahl JE. Cytotoxicity of dental glass ionomers evaluated using dimethylthiazol diphenyltetrazolium and neutral red tests. Acta Odontol Scand. 2001 Feb;59(1):34-9. 
15. Santos RL, Pithon MM, Fernandes AB, Cabral MG, Ruellas AC. Biocompatibility of orthodontic adhesives in rat subcutaneous tissue. J Appl Oral Sci. 2010 Sep-Oct;18(5):503-8.

16. Paradella TC. Glass-ionomer cements in modern dentistry. Rev Odontol UNESP. 2004 Sep-Oct;33(4):157-61.

17. Nogueira Júnior L, Araújo JEJ, Pavanelli CA, Araujo MAM. Histopatological analysis of pulp reactions, in vivo, after cementation of complete crowns with three luting agents: one phosphate and two glass ionomer cements. Rev Odontol UNESP. 1997 Jul-Dec;26(2):517-31.

18. Golin C, Tavares T, Cunha AC. Biocompatibility evaluation of commercial marks of glass ionomer-cement: study in mouse subcutaneous tissue. Rev Bras Odontol. 1992 JanFev:49(1):35-9.

19. Costa CAS, Hebling J, Hanks CT. Effects of light-curing time on the cytotoxicity of a restorative resin composite applied to an immortalized odontoblast-cell line. Oper Dent. 2003 JulAug;28(4):365-70.

20. Shelton RM, Rasmussen AC, Davies JE. Protein adsorption at the interface between charged polymer substrata and migrating osteoblasts. Biomaterials. 1988 Jan;9(1):24-9.

21. Meyer U, Szulczewski DH, Barckhaus RH, Atkinson M, Jones DB. Biological evaluation of an ionomeric bone cement by osteoblast cell culture methods. Biomaterials. 1993 Oct;14(12):917-24.

22. Grecca FS, Kopper PM, Santos RB, Fossati AC, Carrard VC, Acasigua GA, et al. Biocompatibility of RealSeal, its primer and AH Plus implanted in subcutaneous connective tissue of rats. J Appl Oral Sci. 2011 Jan-Feb;19(1):52-6.

23. Onay EO, Ungor M, Ozdemir BH. In vivo evaluation of the biocompatibility of a new resin-based obturation system. Oral Surg Oral Med Oral Pathol Oral Radiol Endod. 2007 Sep;104(3):e60-6.

24. Pameijer $\mathrm{CH}$, Segal E, Richardson J. Pulpal response to a glass-ionomer cement in primates. J Prosthet Dent. 1981 Jul;46(1):36-40.

25. Soheili Majd E, Goldberg M, Stanislawski L. In vitro effects of ascorbate and Trolox on the biocompatibility of dental restorative materials. Biomaterials. 2003 Jan;24(1):3-9.

26. Lewis J, Nix L, Schuster G, Lefebvre C, Knoernschild K, Caughman G. Response of oral mucosal cells to glass ionomer cements. Biomaterials. 1996 Jun;17(11):1115-20.

27. Costa CAS, Hebling J, Garcia-Godoy F, Hanks CT. In vitro cytotoxicity of five glass-ionomer cements. Biomaterials. 2003 Sep;24(21):3853-8.

28. Silva RA, Assed S, Nelson-Filho P, Silva LA, Consolaro A. Subcutaneous tissue response of isogenic mice to calcium hydroxide-based pastes with chlorhexidine. Braz Dent J. 2009 Jan-Feb;20(2):99-106.

29. Garcia LF, Pires-de-Souza FC, Teofilo JM, Cestari A, Calefi PS, Ciuffi KJ, et al. Synthesis and biocompatibility of an experimental glass ionomer cement prepared by a non-hydrolytic sol-gel method. Braz Dent J. 2010 Sep-Oct;21(6):499-507. 